\title{
Characterization of a Novel MDH1 Bacterium from a Virgin Hot Spring Applicable for Gold Nanoparticle (GNPs) Synthesis
}

\author{
Nurul Alam, Manas Sarkar, Trinath Chowdhury, Dipak Ghosh, Brajadulal Chattopadhyay* \\ Department of Physics, Jadavpur University, Kolkata, India \\ Email: "bdc_phsics@yahoo.co.in
}

Received 29 July 2016; accepted 14 August 2016; published 17 August 2016

Copyright $@ 2016$ by authors and Scientific Research Publishing Inc.

This work is licensed under the Creative Commons Attribution International License (CC BY). http://creativecommons.org/licenses/by/4.0/

(c) (i) Open Access

\begin{abstract}
Background: Use of novel microorganisms for beneficial purposes is still remaining a challenging job. This study was designed to isolate, characterize and use of a novel hot spring bacterial strain from a virgin hot spring of Metaldanga, Birbhum, West Bengal, India. Methods: A pure bacterial strain (MDH1) was identified by growing the enrichment culture isolated from Metaldanga hot spring through serial dilution process in a semi-synthetic medium at $\mathrm{pH} 8.0$ and $42^{\circ} \mathrm{C}$ temperature. The novelty of the strain was characterized by 16S-rRNA gene sequence analysis. The bacterium acted as template to synthesize spherical gold nanoparticles (GNPs). GNPs were characterized by using UV-Vis spectroscopy, X-ray diffraction (XRD), dynamic light scattering (DLS) and Fourier transform infra-red spectroscopy (FTIR). Results: The phylogenetic analysis suggested that MDH1 strain (GenBank accession number: KT600031) was affiliated to the family "Pseudomonadaceae" with $99 \%$ homologous to Pseudomonas putida H8234. The coccoid shaped bacterium was gramnegative and facultative-anaerobic which acted as a template to synthesize spherical GNPs with an average size of $12 \pm 3 \mathrm{~nm}$ when examined under transmission electron microscopy (TEM). FT-IR studies revealed the presence of bioactive functional groups which acted as capping and stabilizing agents of the GNPs. XRD pattern confirmed the amorphous nature of GNPs. The Zeta potential (Ъ) concluded the adequate stability of GNPs in an aqueous environment. Conclusions: The present investigation explores the microbial diversity of a virgin hot spring of Metaldanga for its beneficial applications in industry, particularly in the synthesis of the gold nanoparticles.
\end{abstract}

\section{Keywords}

Hot Spring Bacteria, Phylogenetic Characterization, Green Synthesis, Gold Nanoparticles

\footnotetext{
${ }^{*}$ Corresponding author.
}

How to cite this paper: Alam, N., Sarkar, M., Chowdhury, T., Ghosh, D. and Chattopadhyay, B. (2016) Characterization of a Novel MDH1 Bacterium from a Virgin Hot Spring Applicable for Gold Nanoparticle (GNPs) Synthesis. Advances in Microbiology, 6, 724-732. http://dx.doi.org/10.4236/aim.2016.69071 


\section{Introduction}

A hot spring or a hydrothermal spring comprises warm or hot groundwater which is heated by geothermal heat, the essential heat from earth's interior. The hot spring water also contains dissolved solids and several elements such as calcium, lithium, radium, and sulphur. Such geothermal hot spring streams provide a favourable condition for the development of microbial mats, which covers physiologically and phylogenetically different groups of prokaryotes, e.g., chemotrophic sulphur bacteria, cyanobacteria and oxygenic phototrophic bacteria, depending on the temperature, $\mathrm{pH}$, sulphide concentration and some other environmental conditions [1]. Thermophilic micro-organisms present in the hot spring perform a variety of works. One of such important works is metal reduction [2]. The microorganisms belonging to the thermophilic microbial community can fulfil both degenerative and productive functions. Such microorganisms probably carry out global reduction of metals and seem to play a major role in the deposition of minerals in the earth's crust.

The nanoparticles have an important role in modern perspective because of their unique optical, thermal, electrical, chemical, and as well as physical properties that are due to a combination of the large proportion of high-energy surface atoms compared to the bulk solid [3]. The use of nanoparticles offers great potential in environmental remediation (Li et al., 2004) as well as in biomedical anti-oxidants [4]. Many successful chemical and physical techniques e.g., ultraviolet irradiation, aerosol technologies, lithography, laser ablation, ultrasonic sonication etc. are being used for the synthesis of nanoparticles in large quantities comparatively in a short period but all those methods are expensive and sometimes include hazardous chemicals [5] [6]. Increasing attentiveness towards biological processes has led the scientists to develop an eco-friendly approach for synthesis of nanoparticles. The assemblies of nanomaterial using biological systems offer relatively clean, nontoxic and ecofriendly methods for synthesis of nanoparticles. Nowadays, many organisms like living plants, plant extracts, bacteria, fungi and human cells are used to produce nano-composites [7] [8]. Gold nanoparticles (GNPs) are being used in India and China as medicine for revitalization and drug delivery. Furthermore, GNPs have an important role in detection of heavy metals such as lead, cadmium, mercury and arsenic [9].

The hot spring at Metaldanga (Metaldanga, Birbhum, West Bengal, India) is one of the virgin hot springs whose microbial consortium is completely in dark. Several bacterial strains were identified from the hot spring out of which one of the bacterial strains (named MDH1) was isolated and purified through serial dilution technique and characterized for the use in various purposes. The isolated strain from Metaldanga hot spring was found to synthesize spherical gold nanoparticles (GNPs) with average size of $13 \pm 3 \mathrm{~nm}$. The present investigation thus explores the microbial diversity of a virgin hot spring for its beneficial applications in industry, particularly in synthesis of gold nanoparticle.

\section{Materials and Methods}

\subsection{Chemicals}

All fine analytical grade chemicals were purchased from the Sigma Chemical Co., USA; Merck, USA and the Spectrochem Pvt. India Ltd., India. Chloroauric acid $\left(\mathrm{AuHCl}_{4}\right)$ used as gold source, was purchased from Qualigens fine chemicals, Mumbai, India.

\subsection{Isolation and Growth Kinetics of the MDH1 Bacterium}

Mixed population of thermophilic micro-organisms was collected from the soil of the Metaldanga hot springs. An enrichment culture was developed by growing the mixed population culture in a specific semi-synthetic growth medium which contained $0.1 \mathrm{M} \mathrm{Fe}(\mathrm{OH})_{3}, 0.6 \mathrm{~g} \cdot \mathrm{L}^{-1} \mathrm{Na}_{2} \mathrm{HPO}_{4}, 0.33 \mathrm{~g} \cdot \mathrm{L}^{-1} \mathrm{KCl}, 2.5 \mathrm{~g} \cdot \mathrm{L}^{-1} \mathrm{Na}_{2} \mathrm{CO}_{3}, 0.02 \%$ yeast extract and $0.5 \%$ peptone. The mixed population was grown in the medium having $\mathrm{pH} 8.0$ and temperature $42^{\circ} \mathrm{C}$ under anaerobic conditions [10] [11].

After development of enrichment culture, a pure bacterial strain was isolated from the enrichment culture by subsequent serial sub-culturing of the enrichment culture where $\mathrm{pH}$ and temperature were maintained same as in enrichment culture. In the serial dilution process, $1 \mathrm{ml}$ mother enrichment culture (8 days old containing $10^{8}$ cells/ml of cultures) was inoculated in $30 \mathrm{ml}$ sterilized growth medium in a sealed pressure vial (100 ml capacity) and the order of dilution was made up to $10^{9}$. The anaerobic condition inside the vials was maintained by passing $\mathrm{CO}_{2}$ gas through the medium as described earlier [12]. The serial dilution process was repeated several times for isolation of pure bacterial strain from the highest order diluted culture. 
The isolated pure bacterial strain thus obtained was grown in the semisynthetic growth medium at different $\mathrm{pH}$ (range 7.0 to 12.0 ) to optimize the growth $\mathrm{pH}$ of the bacterium. The isolated strain was also grown in the medium (with optimized $\mathrm{pH}$ ) at three different temperatures $\left(42^{\circ} \mathrm{C}, 65^{\circ} \mathrm{C}\right.$ and $\left.72^{\circ} \mathrm{C}\right)$ for optimization the growth temperature. For growth curve of the purified bacterial strain, optical density (O. D.) at $540 \mathrm{~nm}$ of the bacterial growth medium using UV-visible spectrophotometer (UV-3101PC, Shimadzu) was measured at different days of incubation (up to 22 days). The measured ODs were then used to determine the bacterial cells population by comparing with the pre-calibrated bacterial growth curve (cells concentration vs. optical density). The bacterial cell concentrations for optimize $\mathrm{pH}$ and temperature were measured after 10 days of incubation. All these experiments were repeated at least three times to optimize the growth condition of the isolated bacterium.

\subsection{Morphology Study by FESEM}

The isolated bacterial cell morphology was studied by the Field Emission Scanning Electron Microscope (FESEM). The bacterial slide was prepared by fixing the bacterial cells on a clean glass slide with $2.5 \%$ (v/v) gluteraldehyde. The bacterial slide was then dehydrated by incubating for $15 \mathrm{~min}$ in each at graded $(5 \%, 10 \%, 25 \%$ and $50 \%$ ) aqueous acetone. Samples were then air dried and transferred onto a FESEM alumina supports and sputtered with gold by a coater of Blazers. Slides were observed under FESEM (INSPECT F50 SEM, FEI Europe $\mathrm{BV}$, and Netherlands) and photomicrographs of the bacterial cells were taken in single (40×) magnification [10].

\subsection{Phylogenetic Analysis}

Purified bacterial cells were collected by centrifugation of the cultures and the chromosomal DNA of the bacterium was isolated by using standard phenol chloroform technique [11] [13]. The 16 S-rRNA gene fragment was then amplified by using the forward and reverse primers for molecular characterization. The primer selection was on Trial and Error basis. The amplification of the gene was done by using multiple consensus primer sequences at random and all possible combinations.

The primers which amplified the gene were as follows

Forward: 5'CAGGCCTAACACATGCAAGTC3'

Reverse: 5'GGCGGTGTGTACAAGGC3'

The amplified DNA fragment was then separated and eluted from a $1 \%$ agarose gel and purified using the Qiaquick gel extraction kit (Qiagen). The purified PCR product was then sequenced with the same primers. The partial rRNA gene sequence was determined by the di-deoxy chain-termination method using the Big Dye terminator kit and ABI 310 Genetic Analyzer (Applied Bio systems). The sequence similarity was searched on this using BLAST. Phylogenetic analysis of the isolated strain was done by neighbour-joining method where distances between sequences were determined by Kimura's two-parameter model [10] [14]. The confidence limits of the branching were performed by Bootstrap analysis [15]. The partial sequence of 16S-RNA gene was thus obtained and submitted to the GenBank [16]. The isolated novel strain was phylogenetically characterized and named as strain MDH1.

\subsection{Synthesis and Characterization of GNPs}

Well grown (7 days old) bacterial culture of MDH1 strain was taken in a polypropylene tube and the bacterial cell pellet was collected by centrifugation at $8000 \mathrm{~g}$ at $4^{\circ} \mathrm{C}$ for $15 \mathrm{~min}$. The pellet was washed several times by phosphate buffer (pH 7.0) and kept at room temperature for $30 \mathrm{~min}$. A $5 \mathrm{mg}$ of wet cells was added to $2 \mathrm{ml}$ of 1 $\mathrm{mM} \mathrm{AuHCl}{ }_{4}$ solution and incubated for $6 \mathrm{~h}$ at $25^{\circ} \mathrm{C}$. After incubation, the reaction mixture was turned into ruby red colour that showed the precipitation of GNPs in the solution. The as prepared GNPs was then centrifuged (10,000 $\mathrm{g}$ at room temperature) to collect the GNPs. The UV-visible spectrophotometry (Shimazdu, model UV1800, Kyoto, Japan from 300 - $800 \mathrm{~nm}$ ), X-ray diffraction (XRD: The BRUKER D8 ADVANCE), Transmission electron microscopy (JEOL JEM 2100F) were used to characterize the size, shape, surface area and dispersity of the synthesized nanoparticles. The surface charge of the biosynthesized gold nanoparticles were analysed by DLS of Zeta-sizer (Nano ZS-Malvern).

\subsection{Statistical Analysis}

The whole experimental setup was repeated thrice and data were presented with mean \pm standard deviation 
(S.D.).

\section{Results and Discussion}

Several bacterial strains having various morphologies were identified by repeated serial dilution technique from the enrichment culture of Metaldanga hot spring. One of these strain which act as template for synthesizing gold nanoparticles was isolated and purified by serial dilution technique. The isolated MDH1 bacterium strain is maintained by sub-culturing the bacterium in the specific semi-synthetic growth medium. The isolated bacterium is a facultative anaerobic and thermophilic in nature which grow well and multiply in anaerobic condition but survive in presence of oxygen. The maximum growth rate of the bacterium is observed around 7 - 8 days of incubation (Figure 1(a)). The optimum growth $\mathrm{pH}$ and temperature of the strain are at $\mathrm{pH} 8.0$ (Figure 1(b)) and $42^{\circ} \mathrm{C}$ (Figure 1(c)) respectively under anaerobic environment. The bacterial cell morphology was determined by FESEM which showed that the isolated bacterium was coccoid in shape (Figure 2). The Gram staining of the bacterium MDH1 shows that the bacterium is Gram negative in nature. Genomic DNA was isolated from the bacterial sample in which the $\sim 1.5 \mathrm{~Kb}$ DNA fragment was amplified using high-fidelity PCR polymerase (Figure 3). The PCR product was cloned at Not I site in pBS vector. Positive clones were screened by colony PCR. Further clones were screened for difference in pattern by digestion with a 4 base cutter. The clones were sequenced bi-directionally using the forward and reverse primer. The sequence data was aligned and analyzed to identify the bacteria and its closest neighbours. Phylogenetic analysis of the partial 16 S-rRNA gene sequence (1421 nucleotides; GenBank accession number KT600031) clearly shows that the isolated MDH1 bacterial strain is affiliated with the family "Pseudomonadaceae" and closest similarity (99\%) with Pseudomonas putida H8234 (Figure 4, Figure 5).

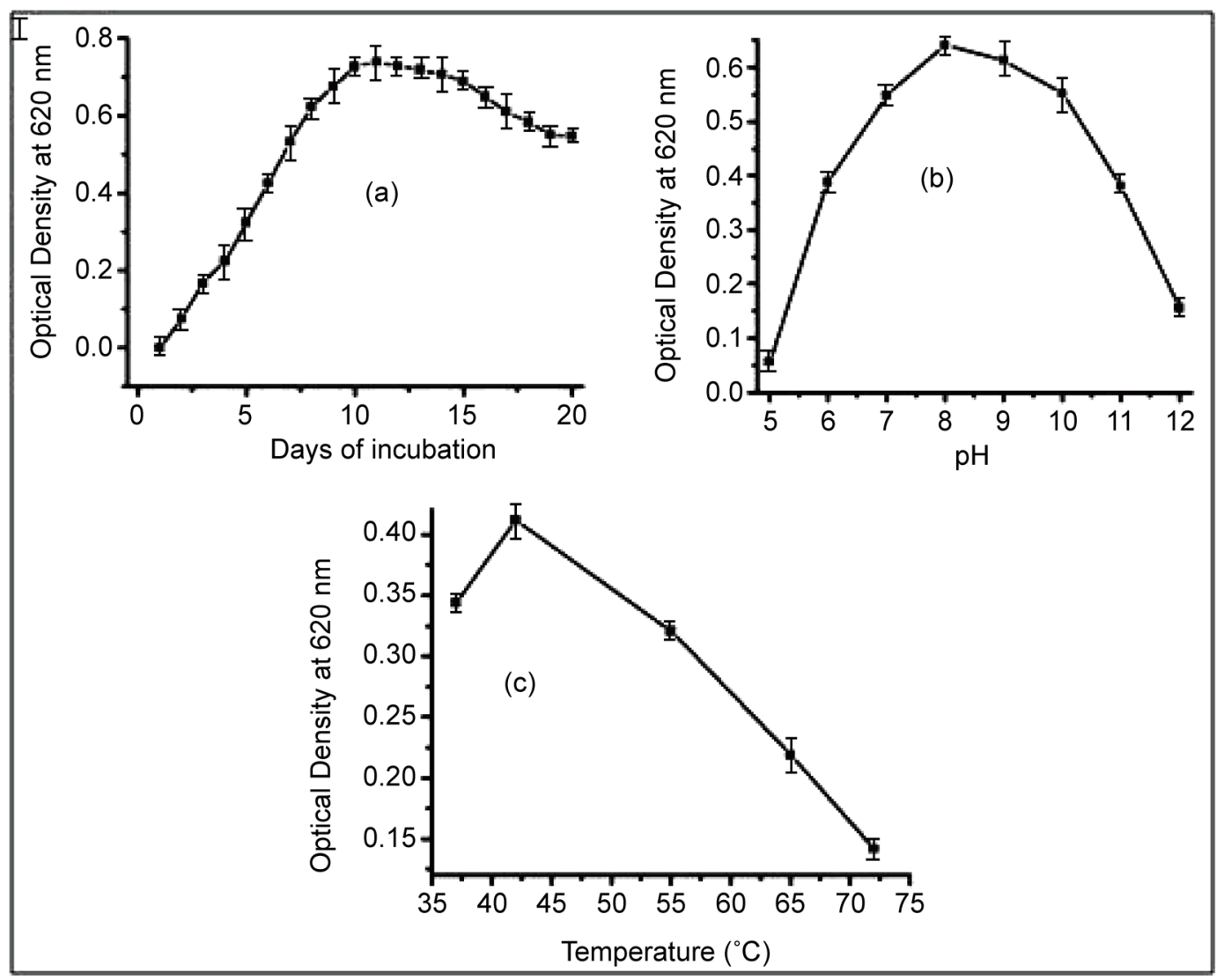

Figure 1. Growth of bacterium MDH1. (a) Growth kinetics of the bacterium while grown in semi-synthetic medium at pH 8.0 and temperature $42^{\circ} \mathrm{C}$ under anaerobic condition; (b) Growth of the bacterium after 10 days while grown in semi-synthetic medium at different $\mathrm{pH}$ and temperature $42^{\circ} \mathrm{C}$ under anaerobic condition; (c) Growth of the bacterium after 10 days while grown in semi-synthetic medium at $\mathrm{pH} 8.0$ and different temperatures under anaerobic condition. 


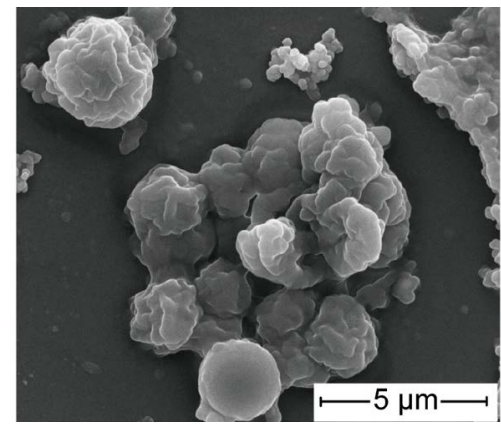

Figure 2. Morphology of MDH1 bacterium taken by FESEM.

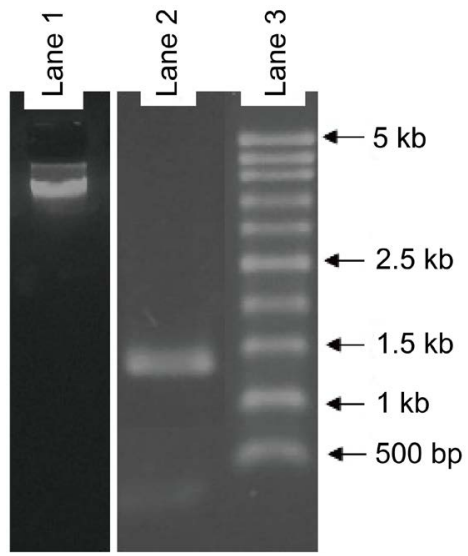

Figure 3. Genomic DNA of MDH1 by gel electrophoresis. Where, Genomic DNA—Lane 1; 16S rRNA gene-Lane 2; 500bp Ladder-Lane 3.

AGAGTTTGATCATGGCTCAGATT GAACGCTGGCGGCAGGCCTAACACATGCAAGTCGAGCGGATG ACGGGAGCTTGCTCCTTGATTCAGCGGCGGACGGGT GAGTAATGCCTAGGAATCTGCCTGGTAGT GGG GGACAACGTTTCGAAAGGAACGCTAATACCGCATACGTCCTACGGGAGAAAGCAGGGGACCT TCGGGCCTTGCGCTATCAGATGAGCCTAGGTCGGATTAGCTAGTTGGTGGGGTAATGGCTCACCAA GGCGACGATCCGTAACTGGTCTGAGAGGATGATCAGTCACACTGGAACTGAGACACGGTCCAGAC TCCTACGGGAG GCAGCAGTGGG GAATATTGGACAATGGGCGAAAGCCTGATCCAGCCATGCCGCG TGTGTGAAGAAGGTCTTCGGATTGAAAGCACTTTAAGTTGGAG GAAGGGCAGTAAGTTAATACC TTGCTGTTTTGACGTTACCGACAGAATAAGCACCGGCTAACTCTGTGCCAGCAGCCGCGGTAATAC AGAGGGTGCAAGCTTAATCGGAATTACTGGGCGTAAACGCGCGTAGGTGGTTGTTAAGTTGG ATGTGAAAGCCCCGGGCTCAACCTGGGAACTGCATCCAAAACTGGCAAGCTAGAGTACGGTAGAG GGTGGT GGAATTTCCTGTGTAGCGGTGAAATGCGTAGATATAGGAAGGAACACCAGTGGCGAAAG CGACCACCTGGACTGATACTGACACTGAGGTGCGAAAGCGTGGGAGCAAACAGGATTAGATACC CTGGTAGTCCACGCCGTAAACGATGTCAACTAGCCGTTGGAATCCTTGAGATTTTAGTGGCGCAGC TAACGCATTAAGTTGACC GCCTGG GGAGTAC GGCCGCAAGGTTAAAACTCAAATGAATTGACGGG GGCCCGCACAAGCGGTG GAGCATGTGGTTTAATTCGAAGCAACGCGAAGAACCTTACCAGGCCTT GACATGCAGAGAACTTTCCAGAGATGGATTGGTGCCTTCGGGAACTCTGACACAGGTGCTGCATG GCTGTCGTCAGCTCGT TT GTGAGATGTTGG GTTAAGTCCCGTAACGAGCGCAACCCTTGTCCTTA GTTACCAGCACGTTATGGTGGGCACTCTAAGGAGACTGCCGGTGACAAACCGGAGGAAGGT GGG G ATGACGTCAAGTCATCATGGCCCTTACGGTCTGGGCTACACACGTGCTACAATGGTCGGTACAGAG GGTTGCCAAGCCGCGAGGTGGAGCTAATCTCACAAAACCGATCGTAGTCCGGATCGCAGTCTGCA ACTCGACTGCGTGAAGTCGGAATCGCTAGTAATC GCGAATCAGAATGTCGCGGTGAATACGTTCCC GGGCCTTGTACACACCGCCCGTCACACCATGGGAGTGGGTTGCACCAGAAGTAGCTAGTCTAACCT TCGGGAG GACG GTTAC CACGGT TT GATTCATGACTG GG GTGAAGTCG TAACAAGGTAAC CGTA

Figure 4. Partial 16S rRNA gene sequence of MDH1. 


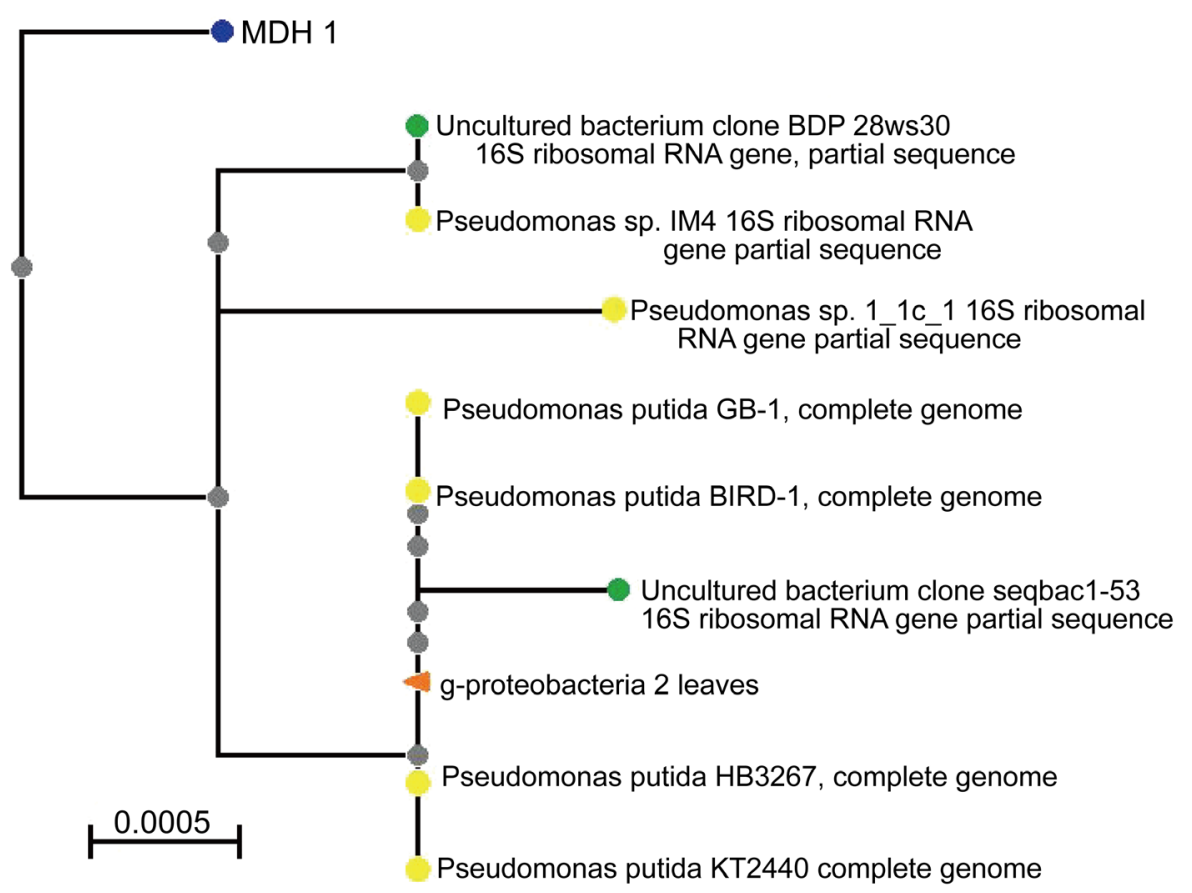

Figure 5. Phylogenetic tree of MDH1 bacterium as determined by Neighbor Joining Method. The sequence similarity was searched on (BLAST) and phylogenetic analysis was done by neighbour-joining method where distances between sequences were determined by Kimura's two-parameter model. The confidence limits of the branching were performed by Bootstrap analysis.

The bio-precipitation of GNPs was easily observed by visual inspection of the reaction mixture which turned from yellowish to ruby-red colour in presence of MDH1 bacterium at $6 \mathrm{~h}$ of incubation (Figure 1(a)). The change of colour indicated the synthesis of GNPs within the reaction medium. The characteristics absorption spectrum of the synthesized nanoparticles recorded by spectrophotometer (Figure 6) was a clear evidence of gold nanoparticles where absorption maximum of GNPs was appeared at $523 \mathrm{~nm}$ as reported earlier [17]. Our earlier works have shown that one hot spring bacteria isolated from Bakreshwar, West Bengal are able to increase the compressive strength of concrete material when incorporated [10] [11] [18] as well as to synthesis silica nanoparticles from silicate substrate. The bacterium BKH1 is found to secrete a protein (Bioremediase; UniProt Knowledgebase under the accession no.: P86277) which possesses biosilicification activity [19]. The protein can act as a template to synthesis silica nanoparticles [20]. The newly isolated MDH1 bacterial strain does not show any biosilicification activity rather it possesses gold leaching activity. The morphology of the bioassisted gold nanoparticles are mostly spherical but a few large particles with different shapes such as triangles and quasi-hexagons also observed from FESEM (Figure 7(a)) and TEM (inset of Figure 7(a)) images. The average particle size of the synthesized gold nanoparticles are about $12 \pm 3 \mathrm{~nm}(\mathrm{n}=100$; excluding the large particles). Average charge of the synthesized particles was found to be negative as confirmed by zeta potential measurement (Figure 7(b)). The negative charges of the synthesized gold nanoparticles indicated the higher stability of the particles.

The crystal structure and phase composition of the as-prepared product were analyzed by XRD (Figure 8). Three prominent peaks were observed in the diffraction pattern, corresponding to the (111), (200) and (220) Bragg reflections of face-centered cubic gold. This clearly indicates that the formation of gold nanoparticles by using a bacterial cells as template. This morphology of synthesized gold nanoparticles as obtained from FESEM or TEM analysis is consistent with that of XRD measurements.

FTIR spectrum of synthesized GNPs showed the presence of characteristic bands for several functional groups (Figure 9). The presence of phenolic groups by $C-C=C$ symmetric stretch $\left(1590 \mathrm{~cm}^{-1}\right)$ and $\mathrm{C}-\mathrm{C}=\mathrm{C}$ asymmetric stretch $\left(1470 \mathrm{~cm}^{-1}\right)$ along with aromatic group by C-H band $\left(1590\right.$ and $\left.2848 \mathrm{~cm}^{-1}\right)$ are observed in the IR spectrum. Presence of aromatic amines $\left(-\mathrm{C}_{6} \mathrm{H}_{5} \mathrm{NH}_{2}\right)$ and aliphatic amines $\left(\mathrm{R}^{\left.-\mathrm{NH}_{2}\right)}\right.$ are confirmed by 


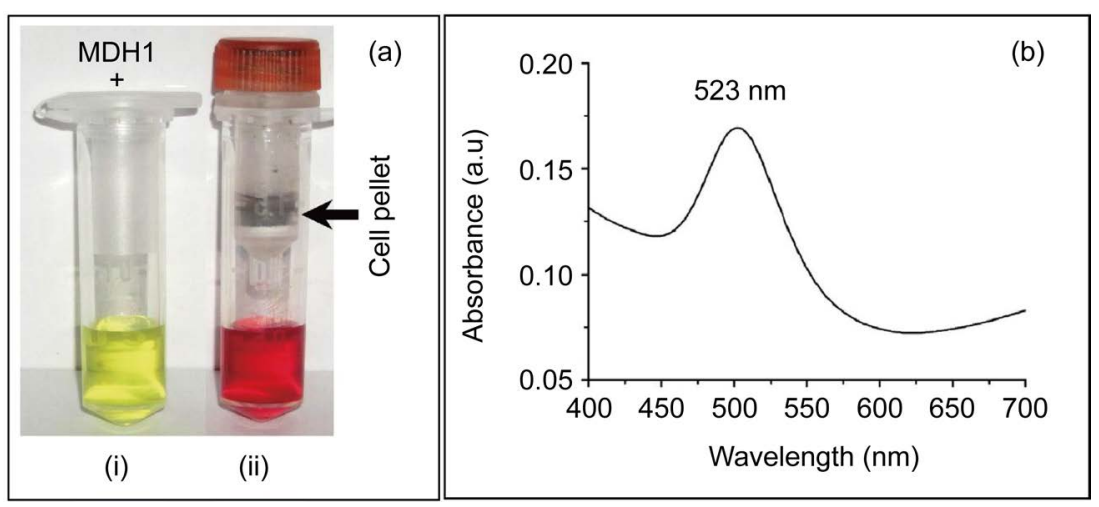

Figure 6. (a) Synthesis of gold nanoparticles from AuHCl4 solution using MDH1 bacterial template, where Figure 6(a-i) is the pure AuHCl4 solution (control) and Figure 6(a-ii) is the bacteria amended AuHCl4 solution after $6 \mathrm{~h}$ incubation; (b) Characteristics UV-visible spectrum of gold nanoparticles.
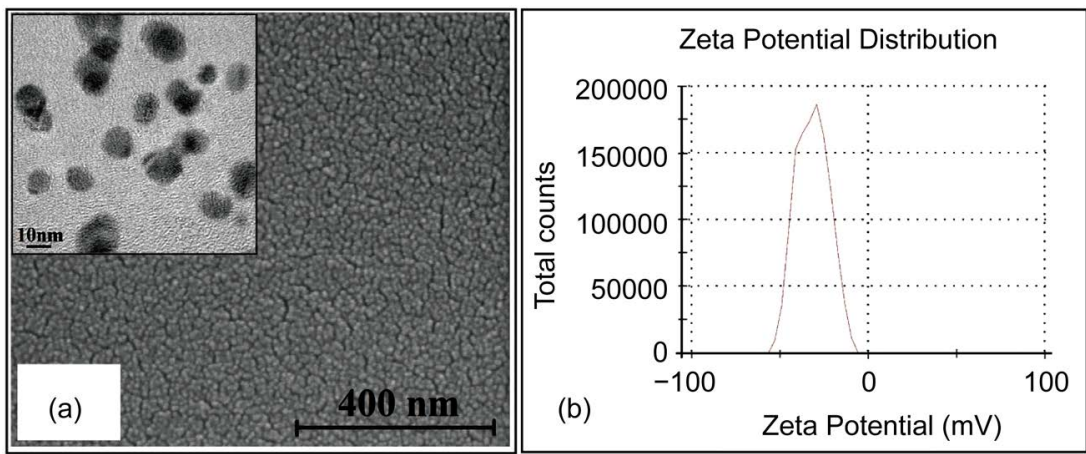

Figure 7. Morphological (size and charge) analysis of gold nanoparticles. (a) FESEM image of gold nanoparticles and TEM view (inset) of it; (b) Zeta-potential of the gold nanoparticles.

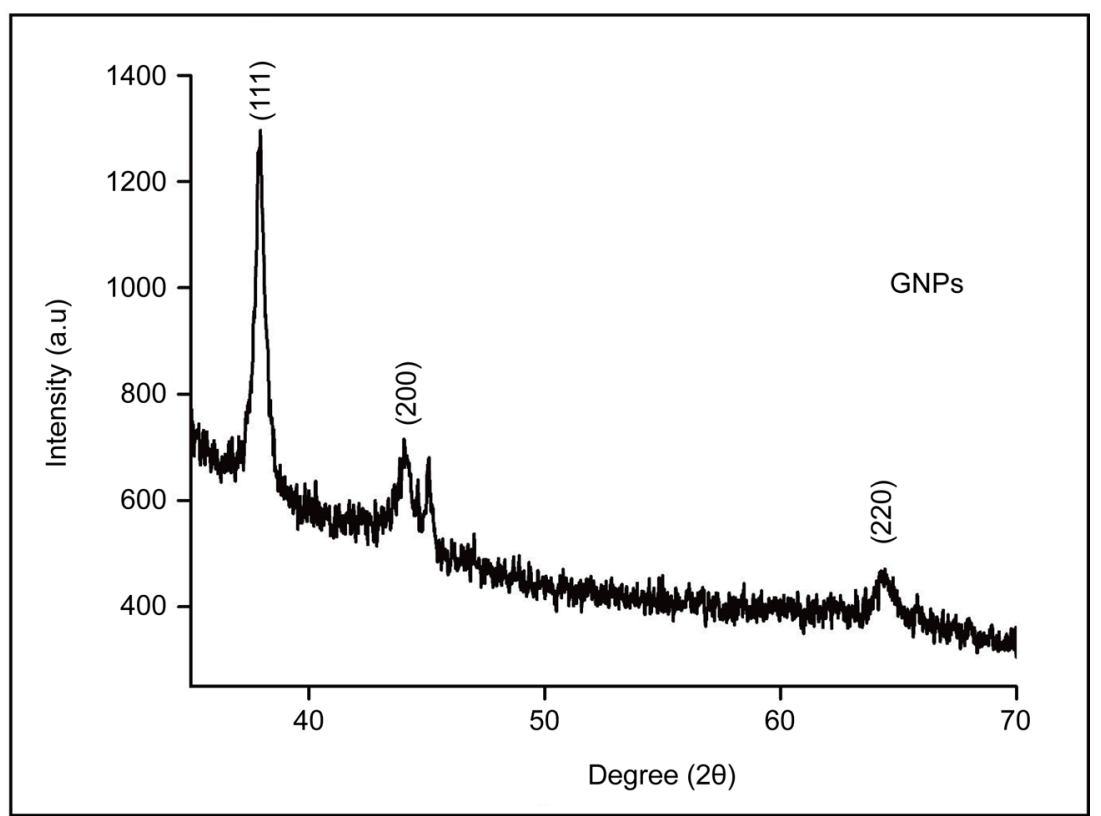

Figure 8. X-ray diffraction pattern of GNPs. Peaks corresponding to the (111), (200) and (220) are the Bragg reflections of face-centered cubic gold. 


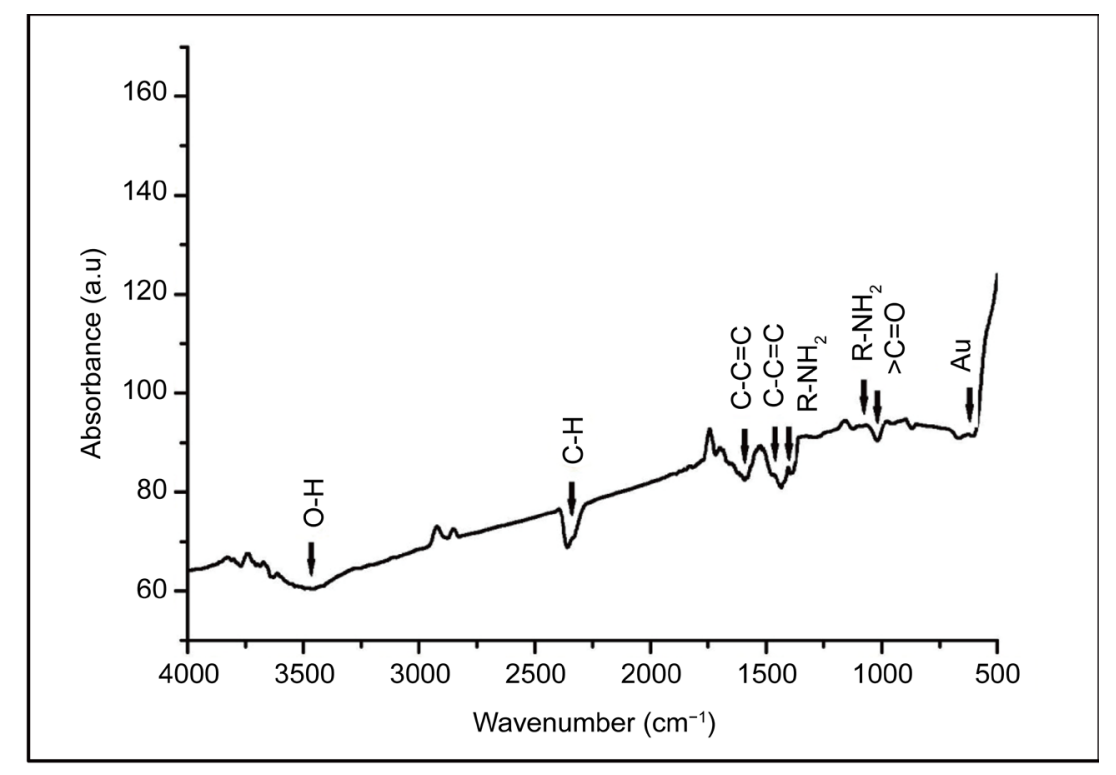

Figure 9. FTIR spectrum of GNPs showing the presence of different functional groups.

$1118 \mathrm{~cm}^{-1}$ and $1390 \mathrm{~cm}^{-1}$ bands. IR band at $1040 \mathrm{~cm}^{-1}$ supports the presence of carbonyl $(>C=\mathrm{O})$ groups of carboxylic acids. IR band for metallic gold is observed near $500 \mathrm{~cm}^{-1}$. A band is observed near $3500 \mathrm{~cm}^{-1}$ due to $\mathrm{O}-\mathrm{H}$ stretching of water molecules and a sharp band near $2310 \mathrm{~cm}^{-1}$ is observed due to presence of $\mathrm{CO}_{2}$. Compounds with free carboxylic acid group $(-\mathrm{COOH})$ or amino group $\left(-\mathrm{NH}_{2}\right)$ were attached to gold surface during GNPs synthesis. Compounds with free hydroxyl and amino group $\left(-\mathrm{OH},-\mathrm{NH}_{2}\right)$ can donate their electron to $\mathrm{Au}^{3+}$ ions to form $\mathrm{Au}^{0}$ and carboxylic and amino moiety can bind to $\mathrm{Au}^{0}$ to stabilize GNPs.

\section{Conclusion}

The bacterium MDH1 secretes few proteins in their growth medium (unpublished data). One of these proteins may be responsible to act as a template for synthesis of gold nanoparticles due to its gold leaching activity. The formation of GNPs via a simple biocompatible bacterial template designates an eco-friendly green cost effective methodology in which spherical and smaller $(12 \mathrm{~nm})$ nanoparticle size can be obtained. It is therefore concluded that isolation and characterization of hot spring bacteria from different hot springs with temperature variations might have potential technological applications in various fields.

\section{Acknowledgements}

The authors highly acknowledge Mr. N. Bala, Jadavpur University for his support in manuscript preparation. The technical and laboratory facilities of Biophysics laboratory, Department of Physics, Jadavpur University are gratefully acknowledged. The technical support of Mr. Samirul Islam, Material Science Department of IACS, Calcutta is also gratefully acknowledged.

\section{Conflict of Interest}

There is no conflict of interest of any kind related to this work.

\section{References}

[1] Tang, K.H., Tang, Y.J. and Blankenship, R.E. (2011) Carbon Metabolic Pathways in Phototrophic Bacteria and Their Broader Evolutionary Implications. Frontier in Microbiology, 2, 165. http://dx.doi.org/10.3389/fmicb.2011.00165

[2] Ilyas, S., Anwar, M.A., Niazi, S.B. and Ghauri, M.A. (2007) Bioleaching of Metals from Electronic Scrap by Moderately Thermophilic Acidophilic Bacteria. Hydrometallurgy, 88, 180-188. http://dx.doi.org/10.1016/j.hydromet.2007.04.007

[3] Ghosh, S.K. and Pal, T. (2007) Interparticle Coupling Effect on the Surface Plasmon Resonance of Gold Nanoparticles: 
From Theory to Applications. Chemical Review, 107, 4797-4862. http://dx.doi.org/10.1021/cr0680282

[4] Patra, J.K. and Baek, K.H. (2015) Novel Green Synthesis of Gold Nanoparticles Using Citrullus lanatus Rind and Investigation of Proteasome Inhibitory Activity, Antibacterial, and Antioxidant Potential. International Journal of Nanomedicine, 10, 7253-7264.

[5] Narayanan, K.B. and Sakthivel, N. (2010) Phytosynthesis of Gold Nanoparticles Using Leaf Extract of Coleus amboinicus Lour. Material Characterization, 61, 1232-1238. http://dx.doi.org/10.1016/j.matchar.2010.08.003

[6] Thakkar, K.N., Mhatre, S.S. and Parikh, R.Y. (2010) Biological Synthesis of Metallic Nanoparticles. Nanomedicine Nanotechnology Biology and Medicine, 6, 257-262. http://dx.doi.org/10.1016/j.nano.2009.07.002

[7] Xu, C., Wang, X. and Zhu, J. (2008) Graphene-Metal Particle Nanocomposites. The Journal of Physical Chemistry C, 112, 19841-19845. http://dx.doi.org/10.1021/jp807989b

[8] Gonçalves, G., Cruz, S.M., Ramalho, A. and Gracio, J. (2012) Graphene Oxide versus Functionalized Carbon Nanotubes as a Reinforcing Agent in a PMMA/HA Bone Cement. Nanoscale, 4, 2937-2945. http://dx.doi.org/10.1039/c2nr30303e

[9] Huang, D., Niu, C., Ruan, M., Wang, X., Zeng, G. and Deng, C. (2013) Highly Sensitive Strategy for Hg ${ }^{2+}$ Detection $^{2}$ in Environmental Water Samples Using Long Lifetime Fluorescence Quantum Dots and Gold Nanoparticles. Environmental Science and Technology, 47, 4392-4398. http://dx.doi.org/10.1021/es302967n

[10] Sarkar, M., Adak, D., Tamang, A., Chattopadhyay, B.D. and Mandal, S. (2015) Genetically-Enriched Microbe-Facilitated Self-Healing Concrete-A Sustainable Material for a New Generation of Construction Technology. RSC Advances, 5, 105363-105371. http://dx.doi.org/10.1039/C5RA20858K

[11] Sarkar, M., Alam, N., Chaudhuri, B., Chattopadhyay, B.D. and Mandal, S. (2015) Development of an Improved E. coli Bacterial Strain for Green and Sustainable Concrete Technology. RSC Advances, 5, 32175-32182. http://dx.doi.org/10.1039/C5RA02979A

[12] Chattopadhyay, B.D., Thakur, A.R., et al. (1994) Inhibitory Role of Aluminium in Methane Emission in Rice Field. Indian Journal of Experimental Biology, 32, 495-500.

[13] Wilson, K. (1987) Preparation of Genomic DNA from Bacteria. In: Ausubel, F.M., Brent, R., Kingston, R.E., Moore, D.D., Seidman, J.G., Smith, J.A. and Struhl, K., Eds., Current Protocols in Molecular Biology, Wiley \& Sons, New York, 2.4.1-2.4.5.

[14] Tamura, K., Peterson, D., Stecher, N. and Nei, G. (2011) MEGA5: Molecular Evolutionary Genetics Analysis Using Maximum Likelihood, Evolutionary Distance, and Maximum Parsimony Methods. Molecular Biology and Evolution, 28, 2731-2739. http://dx.doi.org/10.1093/molbev/msr121

[15] Alfaro, M.E., Zoller, S. and Lutzoni, F. (2003) Bayes or Bootstrap? A Simulation Study Comparing the Performance of Bayesian Markov Chain Monte Carlo Sampling and Bootstrapping in Assessing Phylogenetic Confidence. Molecular Biology and Evolution, 20, 255-266. http://dx.doi.org/10.1093/molbev/msg028

[16] Chattopadhyay, B.D., Alam, N., Sarkar, M. and Chowdhury, T. (2016) Pseudomonas Putida Strain MDH1 16S Ribosomal RNA Gene, Partial Sequence. GenBank.

[17] Chauhan, A., Zubair, S., Tufail, S., Sherwani, A., Sajid, M., Raman, S.C, Azam, A. and Owais, M. (2011) FungusMediated Biological Synthesis of Gold Nanoparticles: Potential in Detection of Liver Cancer. International Journal of Nanomedicine, 6, 2305-2319.

[18] Chaudhuri, B., Alam, N., Sarkar, M., Chowdhury, T. and Chattopadhyay, B.D. (2016) Phylogenetic Characterization of BKH3 Bacterium Isolated from a Hot Spring Consortium of Bakreshwar (India) and Its Application. Advances in Microbiology, 6, 453-461. http://dx.doi.org/10.4236/aim.2016.66044

[19] Biswas, M., Majumdar, S., Chowdhury, T., Chattopadhyay, B.D., Mandal, S., Halder, U. and Yamashaki, S. (2010) Bioremediase a Unique Protein from a Novel Bacterium BKH1, Ushering a New Hope in Concrete Technology. Enzyme and Microbial Technology, 46, 581-587. http://dx.doi.org/10.1016/j.enzmictec.2010.03.005

[20] Chowdhury, T., Sarkar, M., Chaudhuri, B., Chattopadhyay, B.D. and Halder, U. (2015) Participatory Role of Zinc in Structural and Functional Characterization of Bioremediase: A Unique Thermostable Microbial Silica Leaching Protein. Journal of Biological Inorganic Chemistry, 20, 791-803. http://dx.doi.org/10.1007/s00775-015-1266-2 


\section{Submit or recommend next manuscript to SCIRP and we will provide best service for you:}

Accepting pre-submission inquiries through Email, Facebook, LinkedIn, Twitter, etc.

A wide selection of journals (inclusive of 9 subjects, more than 200 journals)

Providing 24-hour high-quality service

User-friendly online submission system

Fair and swift peer-review system

Efficient typesetting and proofreading procedure

Display of the result of downloads and visits, as well as the number of cited articles

Maximum dissemination of your research work

Submit your manuscript at: http://papersubmission.scirp.org/ 